\title{
CHANCES OF EFFECTIVE URBAN POLICY IN HUNGARY UNDER THE INFLUENCE OF THE EUROPEAN COHESION POLICY
}

\begin{abstract}
Edit SOMLYÓDYNÉ PFEIL ${ }^{\mathrm{a}}$
a Széchenyi István University, Faculty of Economics. Győr, Egyetem tér 1. H-9026; somlyody@sze.hu

Cite this article: Somlyódyné Pfeil, E. (2017). Chances of Effective Urban Policy in Hungary under the Influence of the European Cohesion Policy. Deturope, 9(3):141-161

Abstract

The goal of the paper is to search for the state environmental conditions for an effective urban governance by the analysis of the Hungarian processes of the last six years. The survey is focused, on the one hand, on Hungarian towns considered as small and medium-sized towns by European scales; on the other hand, the conditions for the birth of co-operations between these towns and their regions, and among the different sectors are also emphasised. This is the viewpoint from which the paper tries to grab the content and tools of Hungarian urban policy, and the special features of this policy. It is also crucial in this respect how the reform programme of public administration influences governance chances of cities both as regards the location of tasks and the organisational system; and also how much the cohesion policy of the EU and its urban dimension affects the public policy processes.
\end{abstract}

Keywords: urban policy, governance, territorial integration, medium-sized cities, centralisation

\section{INTRODUCTION}

The relationship between nation states and their cities and city regions has changed since their having been activated as economic policy instruments. The European urban network has become the target of EU Cohesion Policy, since its main emphasis is on the competitiveness factor. The role of cities is to maximise their economic opportunities and successes, the most important conditions of which are determined by the frameworks provided by national governments. Therefore, the risk of organisations institutionalising the urban region is their functional limitation (Herrschel, Newman, 2003). Unless they are granted sufficient political and financial power, they are threatened by a loss of economic position and decreasing attractivity of their sites from the aspect of capital, labour force and external firms as well. That is, national framework conditions may support or block co-operations, since the central government is the owner of regulatory and controlling instruments. Therefore, the development path from the hierarchical state has led to the birth of the co-operative state. The emergence of new types of co-operative structures (network governance) justifies that the concentration of forces and collaboration are of key importance even in the most competitive 
economies resulting in the evasion of competition and the coordination of diverse interests in view of achieving an economic goal (Joye, Leresche, 2004).

The economic actors and social sector force the state to make its own operation more effective and change its traditional administrative methods. On the part of the economy there is a demand for the harmonisation of economic, social, ecological and cultural development and for the decrease of the transactional costs. Similarly, the significance of coordination among sectoral policies, and also of conflict management has increased. This can be complemented with the fact that in the field of managing socio-economic problems there is a visible shift from administrative boundaries during state interventions, which induces some changes in the view of space by the state. It is necessary to eliminate the fragmentation of functional spaces which are now broken down into municipal entities, for administrative considerations, as is the abolition of competition among autonomous actors. The way to achieve this can be common planning activity and the definition of joint development perspectives. Non-hierarchical governance (Mayntz, 2004) also expresses political and economic coordination implemented at the scale of urban areas, urban regions.

The theoretical framework for the paper is on the one hand marked by the concept that a city is made what it is by its functions offered for its region, its hinterland (Beluszky, 2004), consequently the concept of urban administration cannot be narrowed down to the city as a single-point spatial pattern. If we start from urbanisation, it shows the economic footprint of big cities, social and economic flows penetrating beyond the administrative boundaries of the city core, which creates a set of administratively separate but functionally networked towns and villages in the hinterland. This, according to Harrison (2012) also means that city in its traditional approach is an obsolete entity, as it is not able to address fundamental social and economic relations. In relation to this concept, the development of cities is seen differently in the frameworks of the post-Fordist economy and in the era of globalisation. The way this was summarised by the Leipzig Charter a decade ago (2007), issued that the precondition of economic spatial development in Europe are the cities. Since then the EU's new 'Territorial Agenda 2020' (2011) about an inclusive, smart and sustainable Europe set out the common goals of the future, which stresses - among other priorities - the promotion of polycentric spatial development and encourages integrated development in cities, rural and specific regions. Urban dimension got a significant emphasis under the roof of the current cohesion policy and urban-rural linkages should be made by partnerships and co-operations highlighting the mutual independency in a given space for making its implementation effective (Farole, Rodriguez-Pose, Storper (2011). The territorial approach is strengthened by 
the European Commission proposed new institutions in the field of urban development, like the Integrated Territorial Investment, the Community Led Local Development and the use of multi-fund programmes for the ERDF and ESF (Altus 2016). According to this expectation, the sustainable urban development suggests the building of urban development platforms and the promotion of capacity building with help of horizontal principles (EC 2014).

In the light of all this the goal of the paper is, taking the previous thoughts into consideration, to search for the state environmental conditions for an effective urban governance by the analysis of the Hungarian processes of the last six years. The survey is focused, on the one hand, on Hungarian towns considered as small and medium-sized towns by European scales; on the other hand, the conditions for the birth of co-operations between these towns and their regions, and among the different sectors are also emphasised. This is the viewpoint from which the paper tries to grab the content and tools of Hungarian urban policy, and the special features of this policy. It is also crucial in this respect how the reform programme of public administration influences governance chances of cities both as regards the location of tasks and the organisational system; and also how much the cohesion policy of the EU and its urban dimension affects the public policy processes.

\section{MAIN FEATURES OF THE HUNGARIAN URBAN POLICY SINCE 2012}

\section{The responses of the Hungarian state to new challenges of urban development}

It is evident that developed countries have witnessed changes in their urban policy due to their incorporation into the national policy agenda. The typology of countries has been around for quite a while which makes a distinction between countries with an explicit or an implicit urban policy (Berg, Braun, Meer, 2007, Harding, 2007, d'Albergo, 2010). We can talk about explicit urban policy when the spatial focus of the state policy has an urban character both during the formulation and implementation of the policy. In contrast, in the case of implicit urban policy, economic and social changes in cities are effected by the measures and interventions of various public policies of a specific country, i.e. these changes are only secondary consequences (d'Albergo, 2010, p. 3.).

On the basis of the analytical system of d'Albergo (2010, p. 4.), direct urban policy means that public urban policy exerts its influence without the inclusion of additional stakeholders in the process of implementation, it relies solely on the co-operation between the central and local governments. Indirect urban policy means that the objective of central decision-makers 
is to create an environment and institutional, legitimisation, financing, cognitive conditions which enable local actors to effect changes in urban matters through their own policies.

National urban policies show a high degree of variance. The new member states were lacking such policy until the very recent period, only a few countries (e.g. Poland, Romania) strive to develop an urban policy under EU impetus. If we compare Hungary with the rest of the EU member states, it is evident that no explicit urban policy has been formulated since the transition. Nonetheless, the National Spatial Development Concept (hereinafter NSDC, 2005) was adopted during the previous European planning cycle with a spatial approach to the absorption of EU funds. ${ }^{28}$ So an implicit urban policy emerged in the form of a planning document which situated the future vision of urban network within the scope of regional policy. If we continue to seek the further characteristic features of urban policy, than their lack will become evident, since the NSDC has neither attained the level of communication, nor the realisation of its content. The ten visions concerning the development of the urban network have not been realised, for the most part, it was the physical reconstruction of city centres which was targeted from EU funds.

The 2014-2020 EU planning period has started, and in the framework of the preparations, the Parliament adopted the Concept replacing the NSDC under the title of National Development and Spatial Development Concept (hereinafter OFTK). A unique feature of the strategy is that, sectoral policies and spatial objectives targeting the development of the country were integrated in a single plan. ${ }^{29}$ The situational analysis of OFTK lays down that the ideas about spatial cohesion have not been realised during the past seven years, spatial inequalities have increased in Hungary and the excessive dominance of Budapest still prevails.

The creation of a „competitive, innovative economy” is featured between mid-term sectoral policy objectives, while the creation of an ,urban network guaranteeing a polycentric spatial structure" features among the territorial objectives. These are added to the so-called regional strategic areas ensuring long-term development which are the following:

- The macro-regional leading role of Budapest,

- urban network and urban policy,

- modern cities which guarantee high quality of life,

- the global development of cities and urban areas based on urban network cooperations,

\footnotetext{
${ }^{28}$ Gov. Decree No. 97/2005. on the National Spatial Development Concept

${ }^{29}$ Gov. Decree 1/2014 (3 January) on National Development 2030 - on the National Development and Spatial Development Concept.
} 
- the economic and cultural modernisation of rural areas, the renewal of relationships between cities and rural areas, etc.

It can be declared that the new strategy reproduces the objectives of the previous NSDC in several respects, and it emphasises the multi-dimensional development of the urban network. In light of the negative experiences, it declares that it is vital to encourage the elaboration of integrated urban development concepts and strategies and the joint planning of urban areas.

When approving the cited OFTK, Hungarian development policy expressed unconditional adaptation to the requirements of the Union. However, as time passed and planning activity was done in the respective territorial units (counties, cities with county rank, district seat towns), the intention for the application of the integrated approach and the connection of towns with their hinterlands faded away. ${ }^{30}$ The strategy back in January 2014 defined the promotion of the joint planning activity of towns and their hinterlands, making it clear that the basic units of spatial developments would be urban areas built on the co-operation of towns and the rural areas, consisting of towns/cities and their hinterlands. This was supplemented by the intention of the strengthening of integrated planning. We have to add that these urban areas are not institutionalised either from administrative or development policy aspects, i.e. they should have been created during the planning procedure. This would have harmonised with the new functional approach promoted by the Union in relation to urban areas that supports so-called interventions at the right scale, i.e. actions that may penetrate from neighbourhood areas through regions right to functional areas, depending on the respective member state (Böhme, Doucet, Komornicki, Zaucha, \& Światek, 2011).

Less than one year later, in December 2014 a government decree was issued on the foundation of a single territorial operational programme, the Territorial and Settlement Development Operational Programme. In the creation of integrated territorial programmes two levels were defined, distinguishing county level and the level of towns with county rank, which was a break from the focus on urban regions. In addition, the Government allocated approximately five per cent of territorial development resources for community led local developments (CLLD). Accordingly, towns with county rank and counties were given preliminarily set allocations of recourses, separate from each other. (The county selfgovernments designed planning activities of all towns and villages in their counties, except for towns with county rank.) At that time the specification of Priority six of the Operational

\footnotetext{
${ }^{30}$ A preliminary of the OFTK was the Government Decree No. 1181/2013 on the principles of the designation of integrated urban area programmes, the implementation of which was neglected. This decree ordered that "Joint urban area planning and co-operations, and also joint developments must be promoted by adequate supports." [Art. 1.)].
} 
Programme itself ("Sustainable urban development in towns with county rank") made the territorial scale of the OP absolutely clear.

What is in the background of the process is that the government had meanwhile changed LAU1 level, abolishing micro-regions used as development and planning units by the previous governments, substituting them with the so-called districts newly created as state administrative units. The districts, established for administrative functions, exclusively, have no representative organs and so cannot articulate territorial interests. The central towns of the districts were given no territorial development competency, so they lack any integrating power for their hinterlands and had no ambitions, either, to carry out coordinating tasks in planning. Consequently, in the 2014-2020 planning period the cohesion force of the mesolevel must be provided by the county self-governments which the legislator deprived of all their public service functions. Accordingly, they were weakened in their administrative capacities, in some counties a staff of 30-40 people should be able to harmonise the planning and development activities of 60-350 separate municipalities, and create the cohesion of the meso-level. Unfortunately, joint developments by municipalities are rare exceptions, given their previous experiences.

To sum it up we can say that the practice of the use of the development resources has receded from the strategic goals, towns and their hinterlands are now separate from each other. This problem concerns both Territorial Development Operational Programme and Rural Development Operational Programme at the same time. Although counties are responsible for both territorial development and rural development, the decision-making mechanism in effect does not allow counties to carry out coordination between the two operational programmes (e.g. the advantage coming from financing from several operational programmes - multi-fund financing), and have no information and influence on the allocation of rural development resources.

According to the methodology of the EU, county self-governments approved their integrated territorial programmes but these features different concepts, depending on the subjective interpretation of the respective counties: e.g. development area to be managed as a single unit, poles, or industrial poles. This does not allow the systematic approach to intervention areas at national scale. The Territorial Development Operational Programme is basically adjusted to the administrative boundaries of the counties, and so county-based resource allocation fails to handle cross-county developments. The negligence of urban area centred view means that this rigid approach cannot be changed. 


\section{The Modern Cities Programme as a new tool of urban policy}

In urban development the Hungarian government has some backlog; no national resources have been allocated for this purpose for one decade. The action called "Modern Cities Programme" seems to make up for this deficiency, implemented from Hungarian resources. It is interesting that towns with county rank are eligible (separated from their hinterlands) for selected support from the Structural Funds and the Modern Cities Programme is also designed especially for these 23 towns. This programme that lacks any programme-like summary was launched by the Government in 2015. A more in-depth analysis reveals its planning background in the OFTK that positioned a total of 27 towns and cities, with another emphasis.

It is a known fact that Hungary has only one metropolitan agglomeration in international terms, namely the metropolitan area of Budapest. At the same time, the second level of the urban hierarchy, - the category of large towns with a population of $300000-500000$ is totally lacking. The next category of towns are qualified only as medium-sized towns according to EU standards. The eight outstanding large cities constituting this category from the aspect of the Hungarian urban network have 100 to 200 thousand inhabitants and are lacking international visibility. This category of cities is explained by intensive suburbanisation. And including the mentioned eight cities, 23 city possesses a special county status.

The national strategy defines as a specific territorial goal the creation of polycentric urban network, which it links to the establishment of a decentralised and networked spatial structure. From a strategic point of view the following areas of intervention were defined in $2014:{ }^{31}$

- development of big cities by strengthening their regional centre and spatial organisational functions;

- developments aiming at the spatial equalisation of the urban network;

- development of the towns in accordance with their economic profiles;

- strengthening of the urban-rural linkages.

It slightly contradicts the above-listed goals that the definition of the strategic future scenarios of cities is made in relation to the capital city, Budapest. According to this towns and cities make the inner and the outer urban ring of the Hungarian capital city, and the inner ring is made by 12 economically dynamic towns that take the burden off Budapest. ${ }^{32}$ In relation to these towns the document envisages the construction of a "Budapest Business Region", and these towns are identified as the agglomeration of Budapest. On the other hand,

\footnotetext{
${ }^{31}$ Parliament Decision No. 1/2014 (3 January): 3.1.4.2 Development of a multi-centred urban network.

32 Towns of the inner urban ring are: Tatabánya, Dunaújuáros, Salgótarján, Vác, Szolnok, Székesfehérvár, Kecskemét, Eger, Veszprém, Jászberény, Esztergom and Gyöngyös.
} 
the 15 towns of the outer urban ring $^{33}$ - according to the concepts - implement a complex economic development programme with a themed focus, as a government objective of utmost importance in this present planning period is economic development. The concept built on the multiplier development impacts of towns is in line with the international mainstream; what would make this urban strategy complete is to integrate these areas by the provision of access and mobility, done via transport development.

The Modern Cities Programme as a tool for the practical implementation of the strategy shows significant alterations compared to the objectives. First, the hinterland of the selected towns are not mentioned, second, financing and control of the programme is done in national competency - and so in the OFTK, within the sets of territorial goals the implementation of the elements of the urban strategies related to the EU 2020 strategy cannot be guaranteed.

The main features of the programme can be briefly summarised as follows: unique, very short and formal co-operation agreements were signed between the government and the respective towns, for 13 towns with county rank until the end of 2016 in the first phase. The interests of the urban regions are neglected, with no sign of any intention to involve stakeholders outside the sector of public administration, or to create any social partnership. (The only exception from this is the city of Miskolc, an old industrial city of Hungary for which research and development and also innovation projects aiming at the increase of the competitiveness of the city and its region are featured in the programme.)

The investments specified in the agreements and the course of their implementation (financial support) is scheduled by the government in individual government decrees issued for the respective cities. In the majority of the cases it is the developments in the city core, with complex economic development programme specified in the case of the city of Sopron. It is promising, on the other hand, that the improvement of the accessibility of these cities, their integration into the network of speedways is widely supported by this government action. A committee consisting of three members delegated by ministries makes decisions on the exact sums of the supports, based on the applications for supports by the cities, and then actual payment takes place under the coordination of the minister leading the Prime Minister's Office. ${ }^{34}$ The list of the planned development interventions in the concrete cities is under

\footnotetext{
33 Towns of the outer urban ring are: Győr, Miskolc, Debrecen Szeged, Pécs, Nyíregyháza, Szekszárd, Székesfehérvár, Kaposvár, Békéscsaba, Zalaegerszeg, Sopron, Nagykanizsa, Szombathely and Ózd.

${ }^{34}$ The Hungarian Government has planned 11 billion EURs in the complete execution of the Modern Cities Programme in the period from 2016-2022. In 2016168 million, while in 2017, 490 million EURs are being spent on the programme. Furthermore, a planned amount of 3226 million EURs will be spent for the year 2018
} 
constant modification. As opposed to the accounting rules relevant for EU projects, the full amounts of the investments are transferred in one lump sum to the bank accounts of the city administrations, and no detailed expenditure account is done. It is striking that the inclusion of sectoral ministers was decided by the government in the implementation phase of the investments.

Finally we may rightly ask whether the co-operation agreements inaugurated by Hungarian urban policy are compatible with the criteria of planning contracts, contract of objectives or programme agreements, successfully applied in other countries (France, Italy, Poland, Switzerland etc.). The institution to be briefly called planning contract hereinafter is a public law contract by its content, the motivation of which is to make the operation of the state more effective, i.e. the linking the use of the state resources to planning activities. The objective of such contracts is taking responsibility by contracting parties, mobilisation of local resources, and at the end of the day the implementation of interventions with regional/territorial impacts. They also manifest modernisation of public administration inasmuch as they are built on the harmonisation of the territorial community and the development objectives of the central state (Somlyódyné Pfeil, 2005; 2014).

A positive side of the interventions is that it is the first time since the regime change that developments at the level of the urban network are initiated. The Hungarian urban policy tool in its present form, however, only partially meets the important requirements against planning contracts. A considerable shortcoming is the lack of guarantees for this contractual relationship, and the experiences collected during the use of Structural Funds are not applied, either. The rules specified do not satisfy the criteria of transparency and accountability, and even the volumes of support are obscure. We may add that no financial contribution and the mobilisation of their own resources is required by the cities, also, the time span of the programme has not been specified. It is only the state budget that reveals it is planned for three years. Finally, the demand for interventions with regional impacts is hard to outline, because although every city was obliged to approve a new integrated urban development strategy in the recent years, these strategies do not have a territorial view. And so the question is still open whether these planning documents are going to found the list of the planned investments, as the strategic foundation of the programme is not visible.

and another 3226 million for the next year (http://hirlevel.egov.hu/tag/modern-varosok-program/, accessed August 25, 2017). 


\section{THE IMPACT OF THE HUNGARIAN PUBLIC ADMINISTRATION REFORM ON THE TOWN SELF-GOVERNMENTS}

\section{Main orientations of the administrative reform as seen from the side of the active state}

In Hungary a change of governance and a turn in the style of government occurred in 2010, resulting in fundamental institutional reforms in the public sector after twenty years. The PAR (Public Administration Reform) has been going on for half a decade, founded since 2015 by the Public Administration and Public Service Development Strategy of the Government of Hungary. ${ }^{35}$ A specific feature of the document is that between the two sectors of the dual state administration its focuses one-sidedly on the territorial organisational structure of central public administration, and only concerns the self-government sector to a minimum extent. In state administration an organisational development called integration is continuously progressing, leading to centralisation.

The selected objectives are summarised as a professional, cost-effective and wellorganised servicing state in the defined future scenario. The new direction of the strategy emphasises, that the main task of public administration is the promotion of the competitiveness of the economy - assistance instead of hindrances, and a deregulation and simplification of the administrative proceedings should take place in order to decrease overregulation. The principal of integration should not mislead the reader, as it is definitely related to the strengthening of the institutional system of territorial state administration at county and district level. The administrative reform of the last four years had a clear-cut organisational focus, hallmarked by the organisation of the system of government offices consisting of 19 territorial units at county level. During the process called integration of the administrative state agents, conglomerates under the leadership of one single juridical person - the County Government Office - were created by the integration of 17 and then three more sectors.

The implementation of an administrative system favouring centralised public administration was started, i.e. the significance of the municipalities sector, which had represented decentralisation in the relatively balanced dual administrative model since 1990, lessened. The weakening of the self-governmental sector can be interpreted from several aspects: the nationalisation of a part of the properties of the municipalities, the deprival of them of their authority and public service tasks, the cutting of their provisions from the central budget and the withdrawal of some of their own revenues and the concomitant shrinking of their autonomy. This can be supplemented by the weakening in their political interest

\footnotetext{
${ }^{35}$ Government Decree No 1052/2015. (16 February) Public Administration and Public Services Development Strategy
} 
representation positions, as after the amendment of the electoral law the major's title now conflicts the member of the Parliament position.

We have to admit, at the same time, that the increase of the operational efficiency of the organisational system of state administration, including the application of modern management tools (planning, control, evaluation, monitoring), and also taking the introduction of planning culture here, are interventions of utmost importance in the modernisation of Hungarian public administration as well. The document seemingly aims at the implementation of all good governance principles typical of the EAS (European Administrative Space). One principle, however, is definitely neglected; this is the participation in public affairs saying that social problems must be solved with the inclusion of the citizens and the civil society and so they must be encouraged to participate in decisionmaking on public policy issues. A fundamental problem from the aspect of effective state is that it does not consider the mobilisation of organisational capacities as a resource.

The concept of consultancy with the clients is provided, which should not be mistaken with the inclusion of citizens and non-governmental and business organisations in the making of public policy. Using a single methodology, the assessment of the satisfaction of the clients was introduced, as was the survey of the needs of the clients, furthermore, in order to safeguard the standard quality of services client charts will be used.

It can be added that as an effect of the financial and economic crisis starting in 2008, rearrangements have occurred in public administration all over Europe. The appearance of the ideal of "good state" accelerated the penetration of expectations for efficiency and effectiveness, but, in addition to thriftiness, flexibility and efforts for co-operations can also be seen in the various systems of administration. In fact, socio-economic organisational function and co-operations have appeared in the working methods of the organs responsible for the local representation of the central governments (Frey, 2003, Balázs, 2015). As we can see, the construction of the Hungarian state turned to another direction that can also be tested through the amendments of the co-operative relations of the municipal self-governments.

\section{The new trajectory of co-operation among municipalities in the shadow of their weakening role}

We can say that the strategy of public administration does not use the concept of decentralisation, and lacks its basic elements as well. Standardisation and uniformisation has in some cases created inoperable, large national institution maintenance organisations. Analysers also warn us (Hegedüs, Péteri, 2015) that the concentration of public utility companies and some communal services to national public service complexes has deprived 
the local self-governments of their important internal organisational and skills capacity, on the one hand, and the economic pillars of the decentralised self-governmental system were badly weakened, on the other hand. The state took over public schools and education, and professional and specialised pedagogical services from the municipalities, depriving thereby municipalities of the most important tasks from local policy and financing aspects. Formerly this field of public policy had undeniably been the greatest motivation of co-operations, in addition to spatial development.

For the small-sized Hungarian local governmental system - in which the principle of 'one settlement, one self-government' still prevails - co-operation among the municipalities is a sensitive issue. Achievement of a size of service area or number of clients that is economical often only possible by joint implementation of services by several municipalities. The regulatory frameworks of co-operation have changed, too, as the opinions of the experts had been taken into consideration and the new Constitution coming into effect in 2012 empowers the legislator to order the compulsory establishment of associations for inter-municipal cooperation. On the basis of this Hungarian local public administration is linked to all settlements from the aspect of political representation, but the organisation of the local offices has moved away from that.

In addition, the intensity of co-operations among the local self-governments has considerably decreased since 2010 , the reasons for which are manifold:

- the principle of locating tasks in a differentiated way,

- taking over of the municipal governmental tasks by the state,

- reduction and limitation of the regulation of associations for spatial development and planning activities, due to the liquidation of the former supra-local spatial unit (the micro-region).

After a colourful institutionalisation of co-operations, the Act on local governments in effect broke the organic development path; the legislator regulates one single type of association, the association with legal entity, with a joint decision-making organ - the type most closely binding the municipalities. The aim of the introduction of the complicated regulatory framework was to favour the service organisational activity of the municipalities in central position, and to stimulate the establishment of associations with large number of participating municipalities and covering extended geographical areas.

The act ordered municipalities with less than 2,000 inhabitants to operate in joint local government offices. These administrative zones, however, are becoming the framework for local public services as well, as from 2016 on the legislator transferred children's welfare and family assistance services in the field of local social affairs to the competency of that 
municipality which is the centre of the local government office, and they are responsible for the provision of the task in the total territory of the zone. But, due to the alignment with the administrative zones, even if the respective municipalities want to choose other means for the provision of the service, the ones that belong to the same basic level service zone must join the same provider of the task - i.e. the right of free association is limited. Simultaneously, towns that are district centres were given professional and methodology centre functions in connection with these services.

When empowering the central municipality, the legislator uses the principle of so-called differentiated location of competencies, assigning more tasks to the municipalities with stronger organisational capacities, which from that time on regulate and implement the respective tasks for the whole of the service zone. The raison d'être of this measure cannot be questioned from the aspect of professional rationale and service quality; on the other hand, it might generate conflicts among the settlement responsible for the task and the local municipalities gradually deprived of their functions. It is a delicate issue if the latter are able in the future to influence the tasks that are relevant for their inhabitant, as there are no regulated mechanisms for the channelling in of their interests.

Due to the mentioned modifications there are scarce institutionalised arenas for horizontal co-operation, and unfortunately this is true not only for rural areas but even more so for urban regions. The missing practice of co-operation raises serious problems for the implementation of strategic planning that is irreplaceable also in public administration, as planning is a substantial field for the realisation of governance, incorporating the communication and joint learning process among the actors of different sectors and levels.

\section{Co-operation in urban areas in the light of an empirical survey}

In order to test the impacts of the regulation in effect in practice, I made a data collection for the examination of the situation of the municipal associations - for this snapshot I chose Györ-Moson-Sopron County as a sample area. ${ }^{36}$ The source of the processed data is the database of the County Government Office.

The number of population in the county - featured as NUTS 3 spatial category in the statistical system of the European Union - was 452 thousand on 1 January 2016. Administratively the county consists of seven districts and 183 municipalities, among the latter twenty have their own sovereign mayor's offices, and 47 joint municipal offices are maintained by the other 163 municipalities. The county has 12 municipalities with town rank.

\footnotetext{
${ }^{36}$ I express hereby my gratitude to the Government Office of Györ-Moson-Sopron County for their professional assistance and the data that they made available for me.
} 
Municipalities co-operate in the frameworks of a total of 52 associations, with 12 municipalities on the average in one association.

The topics on which the associations are organised well reflect the regulatory changes in the background. In the largest proportion, the implementation of the only task that remained at local level in the field of public education - kindergarten education - takes place jointly. This is followed in frequency by the joint provision of a service belonging to another important area: child protection and family assistance service in the area of social services. The associations concentrating on these two human resources services make $60 \%$ of all cooperations till January 2016. Complex associations or ones related to several sectors are exceptional, their proportion is $10 \%$ (Fig. 1).

Figure 1 Topics on which the associations are organised in Györ-Moson-Sopron county, January 2016

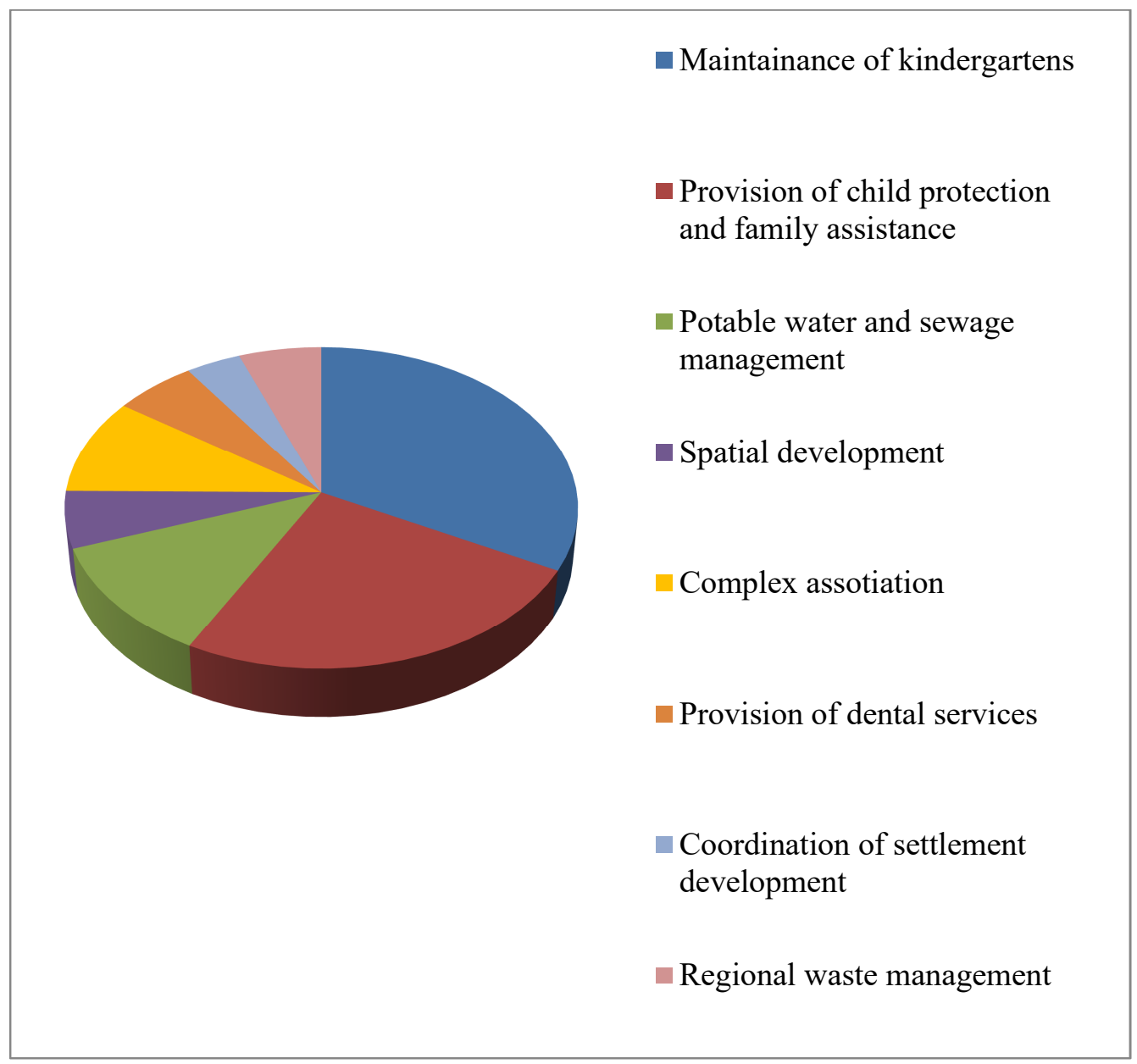

Source: Author's own calculation (database of the County Government Office).

It is an important issue, on the other hand, what happened to the multi-purpose microregional associations eliminated centrally in 2013, which had comprehensively institutionalised the co-operation of municipalities at LAU 1 level both in the provision of 
public services and spatial development and planning. The multi-purpose regional associations were part of the institutional system of spatial development liquidated since then, and so these horizontal co-operations also joined in the vertical branch of governance from the aspect of representation ((Somlyódyné Pfeil, 2010, 2014). In the examined county presently seven (micro)regional associations exist as legal successors and only two of the seven associations co-operate in spatial development and one in the harmonisation of the development of the settlements. Typically only those associations operate in the hinterlands of the cities that are no different in their content from the co-operations of rural areas. This is also true for Györ, a city with county rank, but this county seat city seceded from the successor organisation of the multi-purpose association and does not try to integrate its region. ${ }^{37}$ The majority of the associations have adapted to the changes and their main activity is the provision of special services for their members, or the maintenance of kindergarten or medical services.

On the other hand local self-governments, are obliged, anyway, in accordance with the Act on Built Environment to create their settlement development concept and integrated settlement development strategy. ${ }^{38}$ The result is that plans only tangentially concerning the settlements in the hinterlands were made. In the background of this process we find the fact while in 2010 the act included, in a progressive manner, that the integrated settlement development strategies (may) serve joint planning of several settlements, since then in 2012 the legislator has annihilated this decree.

It is worrying in the light of the situation described above that in the co-operations of the municipalities, joint planning activity is not pursued all, and neither is interest representation towards other state organs or maybe other sectors. The new institutions of regional development have been built out at national and county level. In the National Interest Reconciliation Forum for Regional Development ministries, county self-governments, towns with county rank, and the capital city and its districts have representations, municipalities and their interest representation associations do not. The central actor in regional development is the sub-national level, the directly elected county self-governments that were assigned with the coordination of the development objectives of municipalities and the economic and nongovernmental sector. However, the interest integration of the municipal self-governments has

\footnotetext{
${ }^{37}$ Györ formalises co-operation in the Hungarian-Slovakian cross-border area and is the lead partner of Arrabona EGTC, which territory differs significantly from the hinterland of the city.

${ }^{38}$ Act No LXXVIII of 1997 on the development and protection of the built environment Par. 15. (1) Municipal self-governments may associate for the provision of their tasks in construction affairs, and can also implement their tasks jointly.
} 
no regulated mechanism for the time being, and the assertion of the principle of partnership must be provided by each of the county self-governments in a way on their free choice.

As it is well known the EU introduced several new tools for the present planning period with the objective of sustainable urban development, in the case of which integrated approach is given a special emphasis. The government of Hungary, however, omitted Integrated Territorial Investment (ITI) in their Partnership Agreement made with Brussels, so the application of that will not take place in the present programming period. According to the Union's guideline, in the framework of CLLD (Community Led Local Development) the experiences of the previous Leader programme will be extended to the urban regions, and it will also be an important tool for the strengthening of the urban-rural relationships. In Hungary the government relies upon CLLD as a tool for the revitalisation of the local and regional societies. The call announced requires the establishment of action groups in the field of culture and community building inside of territory of cities.

We can thus conclude that the integration of territorial interests faces several difficulties, especially in cities with their hinterlands. There is no authorisation and financial support by the state which would stimulate the integration of resources and the elimination of competition among territorial stakeholders. This situation contradicts, anyway, the objective of the administrative reform which says that the state intends to promote the competitiveness of the economy. Besides the creation of horizontal relations, the establishment of a vertical co-operation would be just as important among the central level and the territorial and local administrative organs. A direct contractual relationship seems now to serve this purpose between the towns with county rank and the government, but this branch of interest representation is not palpable in the case of all other towns. The county self-governments authorised for the coordination of territorial interests operate on the assignment of the electors, while the representation mechanism of the municipalities is not built out either at meso- or central level. This relationship works in an informal way, which does not guarantee transparency. Interestingly enough it is often members of the Parliament to play a key role as coordinators or lobbyists, MPs whose electoral districts also differ from the hinterlands of the cities.

\section{CONCLUSION}

Urban focus is continuously strengthening in the cohesion policy of the European Union, and it must be applied by the member states during the use of community supports as well. In this 
respect the compliance with administrative structures is not a requirement. The ministers of the member states responsible for urban affairs agreed in the Pact of Amsterdam (2016) on the approval of the Urban Agenda for the Union. An important reason of this is the fact that while within cohesion policy urban areas are emphasised and most requirements concerning the use of supports are relevant for the urban areas, at the level of the member states we are faced with ambiguous implementation and low efficiency (Pact of Amsterdam, 2016). This paper verified this anxiety to some extent in relation to Hungary. The survey conducted, along two principles dominant for the operation of public administration - public governance and the principle of good governance, expressing the normative orientation of the former -, sought the answer to the question what conditions the environment defined by the state provides for Hungarian urban governance. Do the reform objectives set by the state and the tools applied harmonise with each other? In the assessment of the situation the cohesion policy of the EU and some processes of the European administrative space were taken into consideration.

The White Paper on European Governance issued by the European Commission (2001) expressed that the community policies and institutions must get close to the citizens, i.e. the communities at different levels of the society, economic partners and interest representation bodies must be widely included in the making and implementation of public policies. In fact, the integration of the public policies is necessary with a territorial approach, which cannot be achieved if the mechanisms and structures of the territorial integration of society are absent. As consequence of this, multi-level governance is the system in which policy making and execution is divided among different governance levels and local institutions with special purposes (partnerships of the public and private sector), and in which the power “disintegrated" during decentralisation can be integrated again (Böhme at al. 2011).

So far we have reviewed the situation of urban policy from the aspect of the state in Hungary, on the basis of which it has become quite clear that strategic planning is not integrated with the structure of implementation, furthermore, the state does not even strive to position the major and medium-sized cities in the European competition of cities. No pragmatic concept exists for the elimination of the fragmentation of urban areas, and local stakeholders are apparently not interested in the concentration of forces and co-operation excluding competition. The co-operative propensity of local authorities striving for autonomy in Hungary is rather low, there is a continuous absence of territorial thinking.

In practice, co-operative organisations between Hungarian largest cities (with except of the capital city) and their hinterland cover a small number of co-operations with a narrow content, mostly designed for the common provision of some human public services. Frequently, there 
is no comprehensive institutionalised co-operation between the local governments of the urban core and its hinterland. These cases mostly reveal the existence of a direct urban policy since the government does not encourage urban development co-operation between various levels and sectors.

After the turn of the millennium the cohesion policy of the Union was supplemented by the concept of multi-level governance (hereinafter: MLG), focusing on the territorially flexible decision-making mechanism. Territorial cohesion especially requires coordination among territorial tiers and sectoral policies both vertically and horizontally. MLG is not a threat to the state, as it implements governance driven by the public sector (Börzel, Heard-Lauréote, 2009). To the opposite, in unitary states the conditions for the operation of the mechanisms of multi-level governance are usually missing. As our analysis done for Hungary highlighted, at subnational and supra-local level in territorial development and municipal self-governance several forms of institutionalised interest integration were eliminated in 2012. Since then the formation of space has been done with normative tools, exclusively, which is connected to the reinforcement of the administrative boundaries, and this is not favourable for the development of city regions, their becoming single governance units. ${ }^{39}$

As regards coordination among sectors, comprehensive analyses point out that it is still problematic in Hungary, with hardly any existing institutional structures (Finta, 2015). There are no meso-level sectoral policies at all, for which there are two explanations. On the one hand, the territorial organs of state administration have been integrated, apart from a few exceptions, into the county government offices, their organisational sovereignty was liquidated. On the other hand, at the meso-level the county self-governments have no public policy making competency left, their activities are now narrowed down to regional and rural development and also to spatial planning.

Coming from the paragraphs above, in the absence of power decentralisation and parallel to the shrinking of the public policy making competency of the municipal self-governments, the low efficiency of urban governance is forecasted in an etatist administrative environment besides a direct urban policy, despite the strategic objective of the state. The management of this urban policy orientation that is becoming explicit, anyway, is in the competency of the Prime Minister's Office, even though it has no designated organisational unit within the ministry. This urban policy lacks any coordination mechanism; it does not build partnerships with sectors

\footnotetext{
39 The Act on Regional Development and Spatial Planning also regulates an association type, called spatial development municipal association. Regional development associations can be voluntarily established with the exclusive participation of municipalities, but they were not given any sui generis right by the legislator. It is a fact that the boundaries of the associations are defined by the co-operating parties; furthermore, as opposed to the previous situation they do not make a unit of spatial planning. It is a question then how the territorial interest that they represent is integrated into the development agenda created by the central state.
} 
outside public administration and does not promote the co-operation and collaboration of cities and their regions, either. Shrinking spaces of co-operation and coordination can be seen.

The application of the normative principles of good governance required by the international financial organisations is still a timely issue, among other things because they define basic standards of the operation of the public sector that determine the performance of the economy. These values have been taken over by the EU as well. Surveys have justified so far that the six principal elements in the new member states are not adequately applied. The principle of accountability and the rule of law is asserted formally, while there are constant problems with transparency and forward vision. The biggest problems are caused by the requirements of efficiency and effectiveness, and responsiveness. (Ágh 2013, p. 56-57.).

Our analysis reveals that a turn has occurred in Hungary in the government attitude concerning the public sector, and now organic parts of the Hungarian public administration development strategy are strategic thinking, effective governance, quality of the regulation of public administration, creation of integrity in the fight against corruption, i.e. several important principles of good governance. We also have to add a criticism, however, that the conceptual basis of the strategy is restricted to public administration, within that the internal relations of state administration, it has an organisational and human side approach and does not consider the self-government sector, and the economic and non-governmental sector as resources. The all-pervading centralisation leads to introversion, and so the strategy wants to solve almost all tasks with central state tools. In fact, it seems to be obvious that the strategic objectives and certain elements of the implementation are conflicting each other. It is my firm belief that for the municipal self-governments it will cause bigger loss to abandon cooperation as a tool promoting creativity and innovation than the gain the state achieves by the central organisation and organisational rationalisation etc. state-centred public administration is also a break not only with the methods of NPM but also with governance.

\section{Acknowledgement}

The paper was made with the support of Széchenyi István University (Internationalization, initiatives to establish a new source of researchers and graduates, and development of knowledge and technological transfer as instruments of intelligent specializations at Széchenyi University. Project Nr. EFOP-3.6.1-162016-00017).

\section{REFERENCES}

Ágh, A. (2013). Progress Report on the New Member States: Twenty Years of Social and Political Developments. Together for Europe Series, No. 17. Budapest: Budapest College of Communication and Business. 
Altus (2016). The use of new provisons during the programming phase of the European Structural and Investment Funds. Final Report to the Directorate-General for Regional and Urban Policy. European Commission, May 2016. (accessed August 26, 2017).

Balázs, I. (2015). Az államigazgatási hatósági szolgáltatások közigazgatás-szervezési modelljei (Administrative organisational models of state auhority services). Új Magyar Közigazgatás (8) 3, 2-13.

Beluszky P. (2003). Magyarország településföldrajza. Általános rész (Settlement geography of Hungary. General part). Budapest-Pécs: Dialóg Campus Kiadó.

Berg, L. van den - Braun, E.- Meer, J. van den (2007). (eds.) National Policy Responses to Urban Challenges in Europe. Aldershot: Ashgate Publishing Limited.

Böhme, K., Doucet, P., Komornicki, T., Zaucha, J., \& Światek, D. (2011). How to strengthen the territorial dimension of 'Europe 2020' and the EU Cohesion Policy. Report based on the Territorial Agenda 2020. Prepared at the Request of the Polish Presidency of the Council of the European Union. Warsaw. January 16, 2015 from http://ec.europa.eu/regional_policy/sources/docgener/studies/pdf/challenges2020/2011 _territorial_dimension_eu2020.pdf(accessed January 16, 2015).

Börzel, T. A., \& Heard-Lauréote, K. (2009). Networks in EU Multi-Level Governance: Concepts and Contributions. Journal of Public Policy. 29(2), 135-151, Networks in European Union Governance. Retrieved November 02, 2016 from http://www.jstor.org/stabel/40542335

d'Albergo, E. (2010). Urban issues in nation-state agendas. A comparison in Western Europe. Urban Research and Practice, 3(2), 138-158. Retrieved January 07, 2013 from http://www.eukn.org/E_library/Urban_Policy/Urban_issues_in_nation_state_agendas_ a_comparison_in_Western_Europe

EC (2014) Investment for jobs and growth. Promoting development and good governance in EU regions and cities. Six report on economic, social and territorial cohesion. July 2014. Brussels: EC Regional and Urban Policy. http://ec.europa.eu/regional_policy/sources/docoffic/official/reports/cohesion6/6cr_en. pdf_(accessed January 16, 2015).

European Governance. A White Paper. Commission of the European Communities. Brussels, 25.7.2001 COM (2001) 428 final.

Farole, Th., Rodriguez-Pose, A., \& Storper, M. (2011) Cohesion Policy in the European Union: Growth, Geography, Institutions. Journal of Common Market Studies. 49(5), $1089-1111$.

Finta, I. (2015). Az integrált terület- és vidékfejlesztés eszközei és korlátai Magyarországon. (The Tools and Limitations of Integrated Regional and Rural development in Hungary.) Tér és Társadalom, 29 (1), 132-148.

Frey, R. L. (2003). Regional Governance zur Selbststeuerung territorialer Subsysteme (Regional Governance as self-administration of territorial subsystems). Informationen zur Raumentwicklung 8-9. 451-462.

Harding, A. (2007). Globalization, spatial economic change and urban policy. In: Proceedings of the OECD Conference on What policies for globalizing cities? Rethinking the urban agenda. Madrid 29-30 March. Retrieved July 02, 2014 from http://www1.oecd.org/gov/regional-policy/49680222.pdf

Harrison, J. (2012). Life after Regions. The Evolution of City-Regionalism in England. Regional Studies (46) 9, 1243-1260.

Hegedűs, J., \& Péteri, G. (2015). Közszolgáltatási reformok és a helyi önkormányzatiság (Public services reforms and local self-governance). Szociológiai Szemle 2. 88-119. 
Herrschel, T., \& Newman, P. (2003). Die governance europäischer Stadtregionen (Governance of European city regions). Informationen zur Raumentwicklung, 9-10, 543-555.

Joye, D., Leresche, J-P. (2004). Local government versus metropolitan government: the example of the Lake Geneva region. In: Jouve, B., Lefèvre, Ch. (eds.) Local Power. Territory and Institutions in European Metropolitan Regions. London-Portland, OR: Frank Cass. 128-152.

Leipzig Charter (2007). Territorial Agenda of the European Union. Towards a More Competitive Europe of Diverse Regions. (To be presented for adoption by Ministers responsible for Territorial Development on the occasion of the Informal Ministerial Meeting to be held in Leipzig on 25 May 2007.)

Mayntz, R. (2004). Governance in modernen Staat (Governance in modern cities). In: Benz, Arthur (Hrsg.) Governance - Regieren in komplexen Regelsystemen. Eine Einführung. Wiesbanden: VS Verlag für Sozialwissenschaften. 65-75.

Somlyódyné Pfeil, E. (2005). A tervszerződés intézménye bevezetésének időszerüségéről és szükségességéröl (On the timeliness and necessity of the introduction of the institution of planning contracts). In: A tervszerződés rendszerének hazai adaptálási lehetőségei (Final Research Report). Megbízó: Magyar Terület- és Regionális Fejlesztési Hivatal. Témavezető: Somlyódyné Pfeil E. MTA Regionális Kutatások Központja, Pécs.

Somlyódyné Pfeil, E. (2014). The End of Regionalism in Hungary? An Assessment of Local Governance Before and After. In: Pálné Kovács I., \& Profiroiu C. M. (eds.) Regionalisation and Regional Policy in Central and Eastern Europe: Selected Revised Papers from the 21st NISPAcee Annual Conference May 16-18, 2013 Belgrade, Serbia. Bratislava: NISPAcee. 87-107.

Somlyódyné Pfeil E. (2014a). A városrégiók pozícionálásának eszközei Svájcban (Tools of the positioning of city regions in Switzerland). Hardi T., \& Somlyódyné Pfeil, E. (eds.) Városfejlödési trendek és állami szerepek. A györi jármüipari körzet, mint a térségi fejlesztés új iránya és eszköze c. kutatás monográfiái 2. Universitas-Györ Nonprofit Kft. 136-150.

Somlyódyné Pfeil, E. (2010). Hungarian Public Service Reform: Multipurpose Microregional Associations. In: Swianiewicz, P. (ed.) Territorial Consolidation Reforms in Europe. Budapest: Local Government and Public Service Reform Initiative Open Society Institute. 255-264.

Pact of Amsterdam (2016). Urban Agenda for the EU. Agreed at the Informal Meeting of EU Ministers Responsible for Urban Matters on 30 May 2016 in Amsterdam, The Netherlands. Retrieved January 30, 2017 from http:/urbanagendaforthe.eu.

Territorial Agenda of the European Union 2020. (2011) Towards an Inclusive, Smart and Sustainable Europe of Diverse Regions. Agreed at the Informal Meeting of EU Ministers Responsible for Spatial Planning and Territorial Development on 19th May 2011. Gödöllö, Hungary. http://www.nweurope.eu/media/1216/territorial_agenda_2020.pdf. 